\title{
LIFESTYLES OF YOUTHS MANIFESTING RISKY BEHAVIOUR IN SOCIAL AND CULTURAL CONSIDERATIONS
}

\section{STYLE ŻYCIA MŁODZIEŻY PRZEJAWIAJĄCEJ ZACHOWANIA RYZYKOWNE W KONTEKŚCIE ORIENTACJI SPOŁECZNYCH I KULTUROWYCH}

\author{
Joanna Dworakowska ${ }^{1(\mathrm{~A}, \mathrm{~B}, \mathrm{D}, \mathrm{G})}$
}

${ }^{1}$ Katolicki Uniwersytet Lubelski Jana Pawła II

\begin{abstract}
Dworakowska, J. (2018). Lifestyles of youths manifesting risky behaviour in social and cultural considerations. Rozprawy Społeczne, 12(2), 16-22. https://doi.org/10.29316/rs.2018.12

\author{
Wkład autorów: \\ A. Zaplanowanie badań \\ B. Zebranie danych \\ D. Interpretacja danych \\ E. Przygotowanie artykułu \\ F. Wyszukiwanie i analiza \\ literatury \\ G. Zebranie funduszy
}

C. Dane - analiza i statystyki

Summary

The presented paper refers to the lifestyles of youths manifesting risky behaviour. Lifestyle in this paper is understood as a category of evaluative and cultural orientations of the respective group of youths. The first part presents the understanding of the concept of lifestyle available in the subject-matter literature. In further considerations, the perspective of values accepted and pursued by socially maladjusted youths or those at the risk of maladjustment have been selected and discussed. The following paper is of an analytical and descriptive character.
\end{abstract}

Tabele: 0

Ryciny: 0

Literatura: 27

Otrzymano: listopad 2017

Zaakceptowano: kwiecień 2018
Keywords: youths, lifestyle, risky behaviour

\section{Streszczenie}

Prezentowany artykuł dotyczy problematyki stylu życia młodzieży przejawiającej zachowania ryzykowne. Styl życia w niniejszym artykule jest rozumiany, jako kategoria orientacji wartościujących i kulturowych tej grupy młodzieży. W pierwszej części przedstawione zostały dostępne w literaturze przedmiotu koncepcje stylu życia. Dla dalszych rozważań wybrana została perspektywa wartości uznawanych i realizowanych przez młodzież niedostosowaną społecznie i zagrożoną niedostosowaniem. Artykuł ma charakter analityczno-opisowy.

Słowa kluczowe: młodzież, styl życia, zachowania ryzykowne

\section{Introduction}

Lifestyle as a category appears in the social sciences in various contexts; it is present in the reflection on time resources, work, material goods consumption, cultural activity, intellectual activity, recreational behaviour, attitude to values, participation in social and religious life, systems of values and self-identification of people. Interest in the issue is an imperative owing to some specific features of the post-modern world.

The contemporary man suffers of the excess of choice; there is not one way of conduct which could be accepted without any reservations. The reach of changes and the power of their interference in the human life leave a mark on the subsequent generations. The changes result from various factors, both objective and subjective ones. Youths seem to be in a particularly difficult position confused in the culture of pleasure; they meet aggressive proposals for new ways of formulating the rules of conduct, the hierarchy principles and selection of life objectives. This may result in the origination of the ways of life distant from the conventional models. This paper is an attempt of reflection on lifestyle, as a category of evaluative and cultural orientations among youths manifesting risky behaviour.

\section{Definition issues in reference to the conceptual category of 'lifestyle'}

The term 'lifestyle' is differently defined in the subject-matter literature, depending on the assumed sphere of interest and the scope of concern determined by the researcher. One group of definitions reflects the understanding of that conceptual category as a collection of behaviours comprising all of the life activities of a human being and expressed in various forms.

As an example, Andrzej Siciński defines lifestyle as "the scope and form of everyday life behaviours of human beings and groups, specific for their social situation, i.e. manifesting the social standing and perceived as characteristic for that standing and, in consequence, enabling a broadly understood

Adres korespondencyjny: Joanna Dworakowska, Katolicki Uniwersytet Lubelski Jana Pawła II w Lublinie, Wydział Nauk Społecznych, Katedra Pedagogiki Społecznej i Pedagogiki Opiekuńczej, Instytut Pedagogiki, ul. Droga Męczenników Majdanka 70, 20-325 Lublin, e-mail: asiadworakowska@o2.pl, tel.: 8145453 19 Copyright by: Państwowa Szkoła Wyższa im. Papieża Jana Pawła II w Białej Podlaskiej, Joanna Dworakowska

Czasopismo Open Access, wszystkie artykuły udostępniane są na mocy licencji Creative Commons Uznanie autorstwa-użycie niekomercyjne-na tych samych warunkach 4.0 Międzynarodowe (CC BY-NC-SA 4.0, http://creativecommons.org/licenses/by-nc-sa/4.0/). 
social localisation of other people" (Siciński, 1976, p. 15). This does not mean that in determining the lifestyle of groups or human beings we deal with characteristics and separation of all of the manifestations of their life activities, but rather with the multitude of these areas and determination of what is characteristic, typical and considerably permanent within the human behaviour in those areas.

Asking about lifestyle, we explain how structured are the behaviours in comparison to others, which make up the areas represented in the lifestyle solely fragmentary (Czerwiński, 1976). It should be emphasised that "[...] lifestyle is clearly a group characteristics, valid are those behaviours and those forms of behaviours, which orientate the distinctness of one group from the other, and enable behavioural classification to one or other group" (Siciński, 1976, p. 18). There is no society that would have only one lifestyle. The differentiation of lifestyles in many groups and environments may be easily perceived. The features of lifestyle may be considered in reference to one selected community, or the lifestyle of the particular groups living in the selected environment may be considered separately.

Zbigniew Tyszka defines the term from a more operational side. In his opinion lifestyle is "a culturally determined level and method of satisfying needs and pursuing aspirations with the use of opportunities and prerogatives stemming out of the possessed economic and social standing (Tyszka, 1971, p. 105). The author does not treat the lifestyle category as a permanent feature ascribed to a certain class or group, but as a qualitative characteristic feature of an individual position, reflected dynamically, and subject to change from generation to generation. The issue of lifestyle is connected by him with the participation in culture (Tyszka, 1971).

Andrzej Siciński is of a similar opinion, namely that lifestyle is a manifestation of the selection of everyday life behaviour from among the behaviours possible in the respective culture (Siciński, 1976). The author calls such perspective homo eligens - a man making choices. Lifestyle from that perspective is "a manifestation of a certain principle (principles) of selection of everyday life behaviour from among the repertoire of behaviours possible in the respective culture" (Siciński, 2002, p. 79). Lifestyle research in that regard covers social models (models, cultural models and standards of behaviour), with the differentiation between accepted and pursued models. Situations related to the selection of behaviours are an element which constitutes the notion of lifestyle, enabling differentiation between a method and style of life, and also connecting them with the values. The groups of everyday life behaviours, characteristic to a lifestyle, are determined by values (Jawłowska, 1976).
Therefore, instead of behaviour, we may rather speak about conduct, as this refers to more complex and time-spread behaviours which engage many people and objects (Czerwiński, 1976). Adequate to the lifestyle description seems also the term 'activity' in the meaning given to it by Florian Znaniecki. This will be a deliberate action, where the subject of actions experiences facts covered with their activities and is aware of the changes made in the surrounding reality by their actions (Znaniecki, 1971). A similar approach is presented by Leon Dyczewski, who defines lifestyle as "[...] a specific whole of needs, values and pursuits, preferences and behaviours proper to a social group or a human being, which distinguish them from other human beings or groups" (Dyczewski, 1995, p. 150).

Pierre Bourdieu sees social differentiation as stratification of lifestyles based on consumer selections and preferences. The preferences are defined as a collection of symbolic and material preferences characteristic to the members of one group. The author tries to determine how much the routine behaviours of human beings are conditioned by the structural factors and how much they contribute to the consolidation of the structures. The reply to these questions is, in his opinion, the concept of habitus, i.e. a considerably permanent and not necessarily conscious cognitive orientation, which organises the practice and ideas, resulting from the knowledge of the general social structure and reproducing that structure. Human perception is set out by the person's prior experience and upbringing/education, which are determined by the social and economic background in which the person lives. For a human being, habitus is a type of cognitive map of the world, a particular open system of dispositions and procedures of conduct, ensuring to them the correctness in everyday life situations. It is, therefore, responsible for the lifestyle and practices determined with the specific preferences (style of dress, interests, activity in various fields, leisure activities and many other items). All of the behaviours and choices may exceed class divisions. However, they are ascribed with regard to the source to a group of a certain social status (Bourdieu, 2005).

Nevertheless, lifestyle is not only a logical sequence of activities but a sort of configuration, structure, in which human activities are only one of the elements. The concept of lifestyle as a structure is expressed in the definition provided by Andrzej Siciński, which highlights the particular elements making up such understood lifestyle. These are "behaviours differentiated as to the scope and form (and specifically: sequences of such behaviours focused on specific objectives, which means actions and activities); motivation for the behaviours (assigning meaning and values to them); as well as certain functions of objects which are the results or objective, or instruments of such behaviours (to which - in reference to such 
role - also some meaning is ascribed)" (Siciński, 1988, p. 48).

Also related to that lifestyle notion is the quality of life category. In the opinion of Marcin Czerwiński, low or high quality of life is determined, in the subjective perception of a human being, by the relationship between the accomplished style and values. On the other hand, Andrzej Strzelecki and Andrzej Siciński define the quality of life in a broader sense, in the perspective of the level and opportunities of full development and satisfaction from life. The development opportunities are defined by them in the objective aspect, whereas satisfaction from life is combined by them with a subjective perception. Higher quality of life depends on higher satisfaction from life (Strzelecki, Siciński, 1976).

In this analysis lifestyle will be understood as the form of everyday life behaviours of human beings, which express the needs, aspirations, accepted values and life objectives of a person, conditioning their quality of life and resulting from their social position. The term covers human behaviours as well as psychophysical mechanisms underpinning the behaviours, i.e. human aspirations, interest, and also the pursued and accepted values.

\section{Types and socio-cultural context of the lifestyles of youths manifesting risky behaviour}

In the subject-matter literature, there are many classifications and types of lifestyles. The authors refer the term to such areas as work, leisure, or consumption. Most of the available typologies connect lifestyle with belonging to a specific social class, however, although the existence of social classes is an element of discourse among the representatives of social sciences (Gdula, Sadura, 2012), the processes of mobility and intensive migration of cultural models deprived such understood lifestyles of the feature of social separation, isolation or inaccessibility. Today's lifestyle is not only a distinguishing feature but also one that brings hierarchy, although the distance created is often and quite frequently trespassed (Tyszka, 1971).

Many of the existing lifestyle typologies are no longer current, which results from a continuous, incessant change of the social and cultural context and the currently observed disintegration and mixing of lifestyles. The expression of the present day is the variety of individual and social lifestyles - what is happening at the present moment may and will, with high probability, change after some time. Post-modernity is, thus, characterised with cultural discontinuity, occurrence of new conditions for human existence, new methods of thinking and acting. This emphasises the nomadic characteristics of the human nature. Zygmunt Bauman distinguishes four personal models of a contemporary man: stroller, vagrant, tourist and player.
A stroller mingles with the crowd, preserves his anonymity, does not enter into close interpersonal relations, sees all but is not seen himself. He may specifically direct reality, however, without any effect on the fate of the observed people - this gives him the feeling of freedom from responsibility and consequences. The freedom is illusory, based on superficial and episodic nature of contacts. Today's stroller is a consumer who fulfils himself by purchasing goods.

A vagrant, on the other hand, is a man in constant movement, travelling from one place to another without establishing permanent interpersonal ties. In consequence, the vagrant lives from day to day, he does not plan anything, he permanently follows something undetermined, which he cannot name himself. He does not care for what he lefts behind, or for the opinion of the people left by him, he lives an intensive life, practically without scruple.

A tourist differs from a vagrant by starting the journey of his own choice - his objective is to gain impressions, experience, finding 'otherness', however, he soon leaves the places which do not fulfil his expectations. He does not want to get accustomed to new places, he makes casual acquaintances, thanks to which he may remain anonymous, his travelling is an escape from the reality, responsibility and himself. He values new experiences if they differ from the daily domestic ones.

A player is a person who blurs the limits of reality through a play, in which there are no principles or rules, but the play involves risk. It is essential that the player demonstrates slyness and smartness, so as to mislead the opponent. The most important in the play is success, there is no place for mutual support, liking or compassion, the opponent is always a potential enemy (Bauman, 1993). For each of the models, the escape from reality is a characteristic feature; it is the basis of making choices.

Of pedagogic significance seems to be the approach of Andrzej Siciński, presented in the previously mentioned concept of homo eligens, which comes down to claim that understanding social phenomena is impossible without perceiving them from the point of view of the choices made by people in various everyday life situations, choices which are more or less conscious, influenced by some or other factors (Siciński, 1983). Based on that thesis the author distinguishes six types of lifestyles: lifestyle in a situation of limited possibility to make choices, lifestyle consisting in avoiding the making of choices, lifestyle representing the search for the track of life, lifestyle focused on action as the aim in itself, lifestyle focused on the conservative effect of actions, lifestyle focused on actions leading to a change (Siciński, 2002). It must be mentioned, however, that the situation of avoiding the making of choices is in itself a specific type of lifestyle.

Analysing the lifestyles of youths manifesting risky behaviour, a broader context in which the 
behaviour is coded must be considered. This is surely post-modernity, described with such notions as openness, tolerance, variety, freedom and - mainly - pluralism, which is "a cultural and political vision of complex communities. Yet, it means something more. It assumes constant choice between the alternative opportunities" (Gros, 1992, p. 37). Currently, apart from the forms of activity or interest, free choice applies also to moral categories, which results in the shift of limits within which individual objectives may be pursued. Mariusz Jędrzejko claims also that anticipation of the desired changes that fulfil human expectations is supported by 'post-modern prophets', who attribute to a man the right to nearly all free choices, which results in an extraordinary supply of risk (Dobrychłop et al., 2017).

In the post-modern society perceivable is also a certain contradiction - the declarations of high quality of life are made, on the one hand, and, on the other hand, the media culture promotes models which are often unattainable to a young person but are, at the same time, a precondition for the person's feeling of self-esteem. The trend is close to the assumptions for Robert Merton's theory, where the situation of youths resembles the state of anomy - the access to established objectives and values is limited or blocked, on the one hand, and, on the other hand, there are incentives to pursue the objectives and values. This results in frustration and protest manifesting themselves in problem behaviour (Merton, 1957).

In the opinion of Danuta Ponczek and Iwona Olszowy, taking risk lies in the nature of a young man. A natural need of young people is to experiment, checking their capabilities, which is supposed to lead to the knowledge of the rules governing life and learning how to make decisions. The young do not see a direct relationship between their behaviour and health, as the consequences of risky behaviour often emerge only after many years (Ponczek, Olszowy, 2012). Although risk is a part of the developmental standard, such behaviours bring negative consequences to health and safety, social development, personal development and preparing for the adulthood.

In the opinion of Richard Jessor, the risky lifestyle of youths consists of: problem behaviours (use of psychoactive substances such as alcohol, nicotine, drugs; offences and crimes; premature sexual contacts), anti-health behaviours (unhealthy diet, sedentary behaviour in free time, ignoring the principles of safety, missing hygienic habits), risky functioning in the role of a student (truancy, problems with discipline or abiding by the principles of school life, failure to complete school education) (Jessor, 1991). The concept shows the specifics of the lifestyle of that group of youths on the behavioural platform and indicates behaviours that distinguish the group, however, as it has been said earlier, the category covers also some mechanisms being the basis for the behaviours, which will be presented further herein.

\section{Selected dimensions of youths' risky lifestyle}

Values and aspirations form the basis on which specific behavioural patterns are built. They are also a representation of the outlook on life which is emerging during the adolescence. Czesław Czapów claims that the outlook on life of the youths is a central integrating system, which affects the whole of human conduct. It may be merged on various levels, next to the cognitive and axiological sphere, there is also an instrumental sphere, which is treated as the acceptance and selection of means to pursue superior and staged objectives of life (Czapów, 1978).

On the other hand, Franciszka Wanda Wawro indicates that "the direction of evaluative choices of the youths is reflected mainly in the method of applying hierarchy with regard to the criterion of considering their importance in one's own life. This is a basis for formulating life aspirations (personal, social, educational and cultural ones) as well as plans and actions undertaken, more or less consequently in reference to the aspirations, through which the youths will be finally able to practically determine their own changes for selffulfilment. Therefore, it may be assumed that the scope of selecting the values is the basis in directing the actions of a person and making them dynamic" (Wawro, 2008, p. 150-151).

In the subject-matter literature, there is no comprehensive research on evaluative orientations of the youths manifesting risky behaviours. The empiric reports concentrate rather on the evaluation of socially maladjusted youths or criminal youths. As it has been mentioned above, risky behaviour applies to some extent to a significant part of adolescents, as the inclination to experiment and risk has somehow become a developmental standard. However, if it becomes a permanent feature, covering the whole structure of personality of a person, it is treated as a symptom of social maladjustment (Pytka, 1993; Konopczyński, 2014). Krzysztof Ostatszewski claims that "risky (problem) behaviour may be defined as such which is anti-normative and opposed to the social and legal order, causing at the same time a threat to health and development of a person" (Ostaszewski, 2005, p. 112-113). Both problem and risky behaviour may lead to character disturbances of non-uniform symptoms and lead to social maladjustment. Bearing that in mind, further in this paper, the empirical reports regarding values, aspirations and life objectives of socially maladjusted youths are also presented.

The world of values of the youths threatened with social maladjustment (referred to social-therapeutic day centres) has become an element of Paweł Kozłowski's research. The research proves that socially maladjusted youths and those threatened 
with maladjustment are different from the youths in the control group (socially adjusted) with regard to their evaluative choices. The former care more for values which serve the openness to experience and values contributing to the strengthening of the 'I', assessing the values which serve the conservative attitude and those contributing to exceeding the 'I' limits as less wanted. The higher the level of social maladjustment of the youths, the higher the acceptance of values serving openness to experience and the smaller the preference for values contributing to the conservative attitude. The subjects threatened with social maladjustment often prioritised the values important in their life: safety, kindness, achievements, universalism, hedonism, self-determination, conformism, stimulation, tradition, power (Kozłowski, 2016).

The research of Jan Szałański regarding the values of the youths at correction and childcare centres reflect that the respondents do not highly assess competence values such as imagination, logical thinking, intellectualism, independent and broad intellectual horizons. From among moral values, namely helping the others, understanding, purity, salvation, the centres residents have most often selected purity. In the author's opinion the specifics of social maladjustment of such youths is related to constitutionally determined intensity of such behaviour features as "general demand for stimulation, love for danger and adventure, searching for experiences for pleasure, love for unhindered behaviour and sensitivity to boredom" (Szałański, 1993, p. 153-154).

Similarly, it appears from the research of Franciszek Kozaczuk that the juveniles placed two values on the primary positions, namely friendship $(22.3 \%)$ and social life (20.9\%), as ones really pursued. Further positions were occupied by the following pursued values: health (13.7\%), love $(12.9 \%)$, joy of life (11.4\%).

The dominating group among the pursued values proved to be that related to self-transcendence. The youths referred mainly to contact with nature, peace and justice. On the second place was the feeling of self-fulfilment through intellectual development. The subjects cared more for respect, dignity and personal freedom than for wisdom and knowledge. The third group of values were those related to the development of interests. Among those specifically emphasised were: love, health and self-development. Another substantial factor was the group of prestigious values. As perceived by the youths pursued were mainly: smartness in life, comfortable life and material goods. The last positions within that group were occupied by values related to power and social position. The fifth place was taken by interpersonal values, such as friendship, joy of life, social life. In the opinion of the respondents, the ability of social coexistence was not favoured. To a slightly lower extent, as perceived by the subjects, pursued were religious values and those related to establishing a family and the happiness, which they were missing. Important for that group of youths was rejection of the values related to self-fulfilment through learning or the feeling of self-fulfilment through self-improvement. One of the major factors proved to be the value of shaping one's character (Kozaczuk, 1998).

Life objectives and aspirations are an essential source of knowledge of people. The actions of people are most often evaluated from the angle of their intentions. Objectives are assigned a cognitive value, because they seem to be structures more belonging to a human being than observable behaviours. They result from life experiences, consideration and reflection. They regulate the behaviour of a person, bringing order and sense in life and, at the same time, helping to make the future real and discover one's competencies. Objectives represent a category of motives which stimulate global, longterm activities (Zaleski, 1991).

Czesław Czapów emphasises that some of the socially maladjusted youths are characterised with the extreme domination of accommodative trends and sociocentric egoism. Their judgement of life is focused on the fulfilment of objectives and egocentric values rather than the sociocentric ones. Also, the model for personal success is perceived by them not in a calm professional work and performing approved social roles but in a lifestyle assuming alternatively either the comfort of life and material goods or provisional material benefits without any social responsibility (Czapów, 1978).

From the previously cited research of Paweł Kozłowski it appears that socially maladjusted youths, compared to those socially adjusted, focus more on professional and family objectives and less on ludic, prestigious and socially-minded objectives. The youths also have fewer plans for life and present lower differentiation in those plans than the socially adjusted youths. They focus stronger on developing asocial plans as well as friends and family-related, affinity and appearance plans, and weaker on creating educational, social and talent-development plans (Kozłowski, 2016).

It must be noted that the lifestyle of socially maladjusted youths is characterised with unstable worldview structure and absence of a fixed benchmark to accept social models. In the opinion of Franciszek Kozaczuk, the worldview and attitudes presented by the adolescents are a reflection of prosocial values negation. They result from the slight upbringing effects of the family or school. According to that author, "the orientation world of the youths is internally wrecked and includes anatomic elements, aspirations gravitate towards temporary existential needs, whereas the way of satisfying these needs does not reflect any patience or endurance and usually leads to disturbed interactions and conflicts" (Kozaczuk, 1990, p. 105). 


\section{Conclusions}

The approach to risky lifestyles and problem behaviour among youths is subject to constant modifications, mainly thanks to the development of knowledge of aetiology, as well as consequences and phenomena accompanying the risky behaviour. Experimenting, exceeding the limits established by the adult world and risk represent, somehow, a natural development process which cannot be stopped and it is not possible to prevent young people against the existing hazards. Research in the lifestyle of the youths manifesting risky behaviour proves to be particularly important now, that the characteristic feature is a constant change.

A priority demand for the practitioners seems to be a separation of protective factors. Within the social environment, these would be unquestionably: high quality of school education, family life stability, local community resources serving the youths, prosocial activity, participation in religious life, availability of conventional behaviour models in the closest environment and many others.
Of primeimportancefordesigningand supporting the desired lifestyles of the youths is upbringing for values. The contemporary disappearance of a clear hierarchy of values and decline of authority models, whose life could verify the accepted values and their hierarchy, results in an inability on the part of a young man to decide what is good and what is bad. Mariusz Jędrzejko claims that taking together the common features of the current time; we can talk about an age of the chaos of values (Dobrychłop at al., 2017). Many attitudes and life models are therefore a reflection of the missing upbringing to the basic values and, consequently, loss of the sense of life, setting up provisional objectives and moral relativism.

\section{Acknowledgements}

The translation of this paper into English has been financed from the statutory subsidy of The John Paul II Catholic University of Lublin [KUL] obtained in June 2017 for the performance of a research task entitled "Social, cultural and educational considerations of risky behaviour among youths".

\section{References:}

1. Bauman, Z. (1993). Ponowoczesne wzory osobowe. Studia Socjologiczne, 2(129), 7-31.

2. Bourdieu, P. (2005). Dystynkcja. Społeczna krytyka władzy sądzenia. Warszawa: Wydawnictwo Naukowe Scholar.

3. Czapów, Cz. (1978). Wychowanie resocjalizujące. Elementy metodyki i diagnostyki. Warszawa: Państwowe Wydawnictwo Naukowe.

4. Czerwiński, M. (1976). Pojęcie stylu życia i jego implikacje. W: A. Siciński (red.), Styl życia. Koncepcje i propozycje (s. 33-71). Warszawa: Państwowe Wydawnictwo Naukowe.

5. Dobrychłop, A., Jędrzejko, M. Z., Kania, S., Kasprzak, K., Matejek, J., Prufer, P., Sarzała, D., Sieroń, R. B., Szwedzik, A., Taper, A. (2017). Zachowania ryzykowne nastolatków. Nowa jakość ryzyka-ryzyka wielowymiarowe. Ujęcie socjopedagogiczne. Warszawa-Milanówek: Oficyna Wydawnicza Aspra.

6. Dyczewski, L. (1995). Kultura polska w procesie przemian. Lublin: Towarzystwo Naukowe KUL.

7. Gdula, M., Sadura, P. (2012). Style życia i porządek klasowy w Polsce. Warszawa: Wydawnictwo Naukowe Scholar.

8. Gros, F. (1992). Tolerancja i pluralizm. Warszawa: Polska Akademia Nauk.

9. Jawłowska, A. (1976). Styl życia a wartości, W: A. Siciński (red.), Styl życia. Koncepcje i propozycje (s. 205241).Warszawa: Państwowe Wydawnictwo Naukowe.

10. Jessor, R. (1991). Risk behavior in adolescence. A psychosocial framework for understanding and action. Journal of Adolescent Health, 12, 597-605. https://doi.org/10.1016/1054-139X(91)90007-K

11. Konopczyński, M. (2014). Pedagogika resocjalizacyjna. W stronę działań kreujących. Kraków: Impuls.

12. Konopczyński, P. (2016). Wartości, cele i plany życiowe młodzieży nieprzystosowanej społecznie. Kraków: Impuls.

13. Kozaczuk, F. (1990). Styl życia nieletnich i jego wpływ na młodzież szkolną. W: Z. Sobolewski, F. Kozaczuk (red.), Zapobieganie demoralizacji nieletnich (s. 93-106). Rzeszów: Wydawnictwo Wyższej Szkoły Pedagogicznej w Rzeszowie.

14. Kozaczuk, F. (1998). Hierarchiczny układ wartości nieletnich. W: F. Kozaczuk (red.), Wybrane zagadnienia profilaktyki i resocjalizacji dzieci i młodzieży (s. 53-64). Rzeszów: Centrum Doskonalenia Pedagogicznego.

15. Kozaczuk, F. (2005). Świat wartości nieletnich z symptomami niedostosowania społecznego. Rzeszów: Wydawnictwo Uniwersytetu Rzeszowskiego.

16. Merton, R. (1957). Social Theory and Social Structure. Glencoe, Illinois: The Free Press.

17. Ponczek, D., Olszowy, I. (2012). Styl życia młodzieży i jego wpływ na zdrowie. Problemy Higieny i Epidemiologii, 93(2), 260-268. 
18. Pytka, L. (1993). Pedagogika resocjalizacyjna. Warszawa: Wydawnictwo Akademii Pedagogiki Specjalnej.

19. Siciński, A. (1976). Styl życia - problemy pojęciowe i teoretyczne. W: A. Siciński (red.), Styl życia. Koncepcje i propozycje (s. 15-33). Warszawa: Państwowe Wydawnictwo Naukowe.

20. Siciński, A. (1988). Styl życia w miastach polskich. Warszawa: Wydawnictwo IFiS PAN.

21. Siciński, A. (2002). Styl życia. Kultura. Wybór. Szkice. Warszawa: Wydawnictwo IFiS PAN.

22. Strzelecki, A., Siciński, A. (1976). Styl życia a jakość życia. Przyczynek do problemów polityki społecznej. W: A. Siciński (red.), Styl życia. Koncepcje i propozycje (s. 241-263). Warszawa: Państwowe Wydawnictwo Naukowe.

23. Szałański, J. (1993). Przeobrażenia w spostrzeganiu ludzi u wychowanków zakładów poprawczych i wychowawczych. Warszawa: WSPS.

24. Tyszka, Z. (1971). Uczestnictwo w kulturze. O różnorodności stylów życia. Warszawa: Państwowe Wydawnictwo Naukowe.

25. Wawro, F.W. (2008). Wybory wartościujące polskiej młodzieży na emigracji. W: F. W. Wawro (red.), Młodzież a kultura życia w kontekstach społecznych (s. 143-162). Lublin: Wydawnictwo KUL.

26. Zaleski, Z. (1991). Psychologia zachowań celowych. Warszawa: Państwowe Wydawnictwo Naukowe.

27. Znaniecki, F. (1971). Nauki o kulturze: narodziny i rozwój. Warszawa: Państwowe Wydawnictwo Naukowe. 